\title{
JURNAL ILMU PENDIDIKAN DAN EKONOMI
}

Halaman Jurnal: https://journal.staidenpasar.ac.id/index.php/wb Halaman Utama Jurnal : https://journal.staidenpasar.ac.id/index.php

\section{PENERAPAN ADAB MELALUI PENDIDIKAN NON AKADEMIK KEISLAMAN}

Novena Ade Fredyarini S

Email: noveade@gmail.com

\begin{abstract}
Abstrak
Perkembangan zaman berindikasi dengan kemajuan teknologi, berdampak positif dan negatif. Indikasi positif dapat diterima baik oleh masyarakat luas, tetapi indikasi negatif, memerlukan cara pikir dan pandang dalam mengatasi kondisi tersebut. melalui teknologi yang canggih dan kehidupan sosial mulai menurun dalam berinteraksi secara tangible, sehingga memunculkan perilaku tidak baik. Sebagai contoh, siswa kurang mampu berinteraksi sopan dalam mengimlementasikan rasa hormat dengan guru dan orang tua.

Berdasarkan hasil observasi dan wawancara dari beberapa pendidik keislaman pada jenjang pendidikan menengah pertama atau madrasah di Denpasar, dapat menjelaskan proses pembelajaran ekstrakurikuler berbasis keislaman. Melalui pendekatan penelitian kualitatif deskritif mampu mendeskripsikan secara interpretatif dengan dianalisis berdasarkan teori yang berhubungan dengan perubahan perilaku dan karakter. Penerapan adab melalui pendidikan non akademik berbasis keislaman dapat memberikan perubahan baik segi mental, sikap, dan prestasi.
\end{abstract}

\section{Latar Belakang}

Pendidikan sesuai dengan kurikulum 13, dan terdapat dalam Undang Undang nomor 20 tahun 2003, tentang system pendidikan nasional, bahwa pendidikan berdasarkan pada UUD tahun 1945, Pembukaan UUD tahun 1945 dan Pancasila, serta berakar pada nilai-nilai budaya dan sesuai dengan perkembangan zaman. Pada sistem pendidikan dengan lebih mengedepankan pada religi sehingga mengharuskan dalam realisasi proses pembelajar menerapkan unsur religi, sesuai dengan pasal 3, menjelaskan tujuan pendidikan untuk mencerdaskan anak bangsa menjadi berpotensi dan beriman dan bertagwa pada Tuhan Yang Maha Esa. Hal ini mengharuskan bagi lembaga pendidikan untuk melaksanakan proses pembelajaran dengan pendidikan berkarakter sesuai dengan nilainilai agama, budaya, dan perkembangan zaman.

Tuntutan pemerintah dalam mencerdaskan anak bangsa tidak terlepas dari karakter bangsa Indonesia berdasarkan pada Undang-Undang Dasar Republik Indonesia tahun 1945, sehingga pelbagai pihak lembaga pendidikan berupaya dengan inovatif dan kreatif 
dalam mencerdaskan siswa. Seperti pernyataan Rusn dalam Imam Al-Ghazali ( 1994: 4), pendidikan merupakan proses sejak lahir hingga dewasa, dalam memeroleh ilmu pengetahuan pada proses pembelajaran secara bertahap. Orangtua dan masyarakat bertanggungjawab terhadap mereka hingga manjadi manusia yang sempurna dengan pendekatan pada Allah. Demikian halnya dengan H. Fuad Ihsan menyatakan pendidikan, usaha manusia menumbuhkan dan mengembangkan potensi baik rohani dan jasmani sesuai dengan nilai-nilai masyarakat dan kebudayaan.

Nilai karakter seseorang dipengaruhi oleh lingkungan sekitar. Melihat kondisi saat ini, pengaruh teknologi sangat berpotenis bagi perkembang seseorang dalam berpikir dan berperilaku. Dengan perkembangan teknologi yang canggih, semua dapat diinput dan ditelusuri melalui media online. Sehingga memudahkan seseorang dalam memeroleh sesuatu yang diinginkan. Seperti jual beli barang, mencari informasi, bersilaturahmi, dan pembelajaran melalui virtual. Situasi saat ini, yaitu masa pandemi lebih fokus pada media sosial dalam berinteraksi, sehingga lebih rendah interaksi sosial dalam kehidupan seharihari. Tetapi hal tersebut tidak mengurangi proses pembelajaran di lembaga pendidikan.

Lebih intensif dalam penggunaan media handphone dapat meningkatkan rasa kebutuhan pada setiap individu, berkurangnya nilai sosial, dan mengakibatkan perubahan perilaku. Pada masa milenial lebih mengedepankan teknologi. Sehingga nilai-nilai moral menghormati berkurang. Pada masa orde baru, siswa masih memiliki rasa hormat dan sungkan pada orangtua dan orang yang lebih tua. Sebagian besar dari mereka mengerti etika dan bersikap sopan pada lingkungan sekitar. Sebagai contoh, pada lingkungan sekolah siswa selalu menganggukkan wajah atau mengucapkan salam pada guru, dan berusaha untuk menghindar bila bertemu guru karena merasa sungkan. Demikian juga pada saat pembelajaran, siswa dengan iklas mengerjakan tugas yang diberikan oleh guru dan tidak melakukan penawaran atau menolak tugas yang diberikan tersebut. apabila siswa kedapatan melakukan kesalahan, siswa menerima hukuman atas kesalahan dan mengakui kesalahan. Kondisi tersebut juga didukung oleh orangtua dan menyerahkan pendidikan baik formal maupun informal di sekolah. Orangtua percaya pada guru, bahwa guru adalah penganti orangtua di sekolah dan berkewajiban mendidik siswa dalam sikap, keterampilan, dan ilmu pengetahuan.

Dengan perkembangan zaman yang semakin maju, membuat interaksi sosial berkurang. Kehidupan disibukkan dengan pekerjaan yang bersifat mandiri. Pekerjaan di selesaikan dengan gotongroyong atau bersama-sama berkurang, berganti dengan mesin. Budaya kebersamaan dan saling menghormati mulai luntur, karena kesibukan masing- 
masing, sehingga hal yang terbiasa dilakukan, seperti menyapa, berkumpul untuk ronda malam, saling membantu antar tetangga bila mengalami kesulitan.

Pada masa sekarang, tetangga sendiri terkadang di sekitarnyanya tidak mengetahui kondisi masing-masing tetangganya. Demikian halnya yang terjadi pada lembaga pendidikan, siswa kurang menghormati guru, dan apabila siswa ditegur, siswa tersebut akan membela diri dengan berbagai alasan. Terkadang siswa berani menatap guru tanpa rasa takut ataupun sungkan. Apabila terjadi permasalahan di sekolah, terkadang orangtua tidak menerima dan menuntut secara berlebihan.

Hal ini salah satu dampak berkurangnya sikap yang tersirat dalam butir Pancasila, sila kedua dan ketiga. Kebiasaan yang menjadi contoh pada lingkungan sekitar dan generasi selanjutnya perlahan mulai memudar. Kondisi tersebut memengaruhi generasi selanjutnya sehingga memengaruhi ahklak seseorang. Dalam mengatasi situasi tersebut pemerintah telah berusaha dalam mengaplikasi di kehidupan sehari-hari melalui lembaga pendidikan dengan kurikulum 13 tersebut, mengandung pendidikan berkarakter. Melalui pendekatan Ketuhanan Yang Maha Esa dapat meningkatkan ahklak siswa. Suyanto (2009) menyatakan, bahwa karakter merupakan cara berpikir dan berperilaku masing-masing individu dalam kehidupan dan bekerjasama di lingkungan keluarga, masyarakat, bangsa, dan negara. Pentingnya menanamankan karakter dalam dunia pendidikan untuk membantu pemerintah dalam membentuk manusia yang berkarakter. Melalui sistem pendidikan formal dan informal dapat membantu meningkatkan sikap dan perilaku siswa menjadi lebih beriman dan berahklak mulia.

Dalam mendeskripsikan tulisan ini dengan menggunakan metode deskripsi longitudinal dan metode ekspos facto. Metode ini digunakan untuk memudahkan dalam memahami maksud penulis, dalam menjelaskan dan mendeskripsikan keadaan yang sedang berlangsung pada masa sekarang. Fenomena yang terjadi dalam proses kegiatan ekstrakuler berbasis keislaman terdapat hubungan sebab akibat karena melalui proses kegiatan ekstrakurikuler dapat merubah adab dan perilaku menjadi lebih baik dari sebelumnya dan dapat menjadi acuan bagi lembaga atau instasi pendidikan. Data didapatkan dari survey di lingkungan pendidikan tingkat sekolah menengah pertama dan sekolah menengah utama. Melalui pendekatan penelitian kualitatif deskritif mampu mendeskripsikan secara interpretatif dengan dianalisis berdasarkan teori yang berhubungan dengan perubahan perilaku dan karakter. Penerapan adab melalui pendidikan non akademik berbasis keislaman dapat memberikan perubahan baik segi mental, sikap, dan 
prestasi. Melalui pemikiran penulis dan pandangan para ahli dapat melengkapi penulisan jurnal ini.

\section{Penerapan Adab dalam Kehidupan Masyarakat.}

Adab merupakan nilai-nilai ketaatan kepada Allah berdasarkan pada pendidikan moral dan keseluruhan dari kegiatan ibadah, serta pengetahuan menjaga diri dari sikap yang salah. Selain itu adab merupakan aturan dan kaidah yang telah diterima dalam kehidupan sehari-hari di masyarakat. Dengan adab yang baik, akan diikuti dengan ahklak baik pula. Dengan adab berbicara sopan dan beretika akan menunjukkan perilaku baik dan diterima oleh masyarakat. Ahlak merupakan perilaku yang fundamental dalam kehidupan bermasyarakat. Dengan berakhlak baik, segala interaksi sosial menjadi damai dan sejahtera. Seperti yang terdapat dalam hadits (HR at-Tirmidzi), bahwa

"Bertakwalah kamu kepada Allah di mana pun berada. Iringilah perbuatan buruk yang sudah dilakukan dengan perbuatan baik yang dapat menghapusnya. Dan berakhlaklah kepada orang-orang dengan akhlak yang baik."

Dalam hadits tersebut menyatakan bahwa setiap manusia hendaklah memiliki adab yang baik, berbuat baik dan bertaqwa pada Allah, sehingga dosa-dosa akan dihapuskan. Ketaqwaan wajib diterapkan dimana saja, tidak memandang tempat dan jabatan seseotang. Keburukan yang terus menerus sebaiknya dihindari, karena kecendrungkan manusia berpotensi membuat keburukan kepada sesama untuk kepentingan pribadi. Manusia memiliki dua kecenderungan akhlak, yakni mahmûdah (terpuji) dan madzmûmah (tercela). Manusia berlaku tercela ketika nafsu lebih menguasai daripada hati nuraninya. Egoisme untuk memuaskan diri sendiri atau golongan sering kali membuat kita lupa diri kepada hak-hak orang lain, meremehkan orang lain, menyudutkan orang lain, bahkan menyakiti orang lain.

Dalam kehidupan sehari-hari setiap orang menghadapi berbagai ragam watak dan karakter setiap orang. Hendaklah menjalani kehidupan dengan berusaha memberikan yang terbaik. Apabila mendapatkan perilaku baik oleh orang lain, hendaknya berterima kasih dan membalas kebaikannya dan apabila mendapat perlakuan buruk, hendaknya bersabar. Orang bersabar terhindar dari pergaulan yang tidak baik. Ahlak dalam pergaulan terlihat dalam kehidupan sehari-hari, baik dan buruknya seseorang, tidak dilihat berilmu, pangkat dan kedudukan. Orang akan bersimpati apabila orang tersebut mencerminkan ahlak baik, dengan menunjukkan kebaikan, senyuman, menebarkan kegembiraan, dan membantu 
sesama. Ayat dalam Alquran memerintahkan manusia agar menghiasi diri dengan ahklak mulia serta memberikan kabar gembira tentang surga, seperti yang terdapat dalam Ali Imran: 133-134.

"Dan bersegeralah kamu kepada ampunan dari Rabbmu dan kepada surga yang luasnya seluas langit dan bumi yang disediakan untuk orang-orang yang bertaqwa (yaitu) orang-orang yang menafkahkan (hartanya) baik di waktu lapang maupun sempit, dan orang-orang yang menahan amarahnya dan memaafkan (kesalahan) orang. Allah menyukai orang-orang yang berbuat kebajikan."

Allah menjanjikan pada manusia surga yang luas dengan isinya bagi orang-orang yang bertaqwa dengan menjalankan syariat agama dengan kafah. Manusia harus mencari nafkah dan menafkahkan di jalan Allah, menahan amarah, dan memaafkan kesalahan orang lain. Pentingnya kesadaran diri pada alam dan sang pencipta, sehingga dapat menanamkan rasa iman, rasa cinta pada Allah, rasa hormat pada orangtua.

Fenomena menurunnya karakter seseorang, pentingnya lembaga pendidikan membentuk siswa menjadi berahklak yang merupakan indikator utama pada generasi selanjutnya. Terkait dengan pendidikan berbasis karakter, Koesoema (2010: 135) mengemukakan bahwa pendidikan karakter dapat dikatakan sebagai wacana, apabila tidak dipahami secara menyeluruh dan tidak tepat sasaran. Sehingga akan dipahami secara parsial dan bersifat kontraproduktif. Pendekatan parsial harus didasari dengan pedagogik dalam menanamkan nilai-nilai moral dalam pendidikan berkarakter. Dalam lembaga pendidikan pendidikan berkarakter dapat diterapkan pada lingkungan kelas, membangun kultur sekolah, dan komunitas. Pada lingkungan kelas, proses pembelajaran pentingnya intraksi dalam pembelajaran. Konteks pembelajaran memberikan pemahaman materi dengan saling berdialog. Guru mampu mengelola kelas, membuat dan melaksanakan perangkat kelas, memberikan dan menunjukkan pendidikan sesuai materi dan pendidikan moral/sikap. Dalam membangun kultur sekolah, pentingnya membentuk pranata sosial sekolah dengan menerapkan kedisiplinan dan nilai- nilai kejujuran., sehingga pesan moral yang disampaikan terlihat jelas dengan mengikuti aturan dan peraturan sekolah yang telah disepakati dan konsisten, sehingga memunculkan rasa tanggujawab dan nilai-nilai kejujuran. Komunitas sekolah berperan penting di lingkungan masyarakat.

Komunitas sekolah bersama-sama mewujudkan visi dan misi sekolah yang tertuang dalam kurikulum 13 sekolah tersebut, dalam mengaplikasikan kegiatan interaksi sekolah. Masyarakat di luar lingkungan sekolah, seperti keluarga dan masyarakat umum memiliki tanggungjawab moral untuk mengintegrasikan pembentukan karakter dalam konteks 
kehidupan bermasyarakat. Sehingga dapat mewujudkan masyarakat saling menghargai tatanan sosial secara bersama-sama. Melalui integritas pendidikan berkarakter di lingkungan masyarakat memunculkan tanggungjawab bersama dalam meningkatkan pendidikan berkarakter dan memperbaiki penurunan nilai-nilai moral sehingga mampu membina dan menjaga kesejahteraan sosial.

Melalui pendidikan berkarakter pada dunia pendidikan siswa dapat menerapkan dalam kehidupan bermasyarakat. Biasanya dunia pendidikan selalu menonjolkan sekolah masing-masing dengan menampilkan prestasi siswa. Dalam mengekspresikan prestasi tersebut, tentunya siswa harus menunjukkan adab yang baik di lingkungan masyarakat banyak dalam mengilmplementasikan keilmuannya. Tidak hanya prestasi yang ditonjolkan tetapi juga ahklak dalam berhadapan dan berinteraksi dengan komunitas masyarakat. Seperti bertuturkata sopan, berperilaku dan beretika sopan serta bertanggungjawab dengan diri sendiri dalam menunjukkan prestasinya.

Berdasarkan pernyataan Abdulsyani (2007:37-38), bahwa manusia memiliki perbedaan dalam setiap individu, baik sifat, perasaan, gaya meniru, dan pemahaman. Meluasnya pertalian keluarga membangun sikap solidaritas sehingga dapat memperkokoh dan memperluas ikatan kekeluargaan dan dapat menghadapi bahaya, baik ancaman dan perselisihan. Setiap kelompok tentu mempunyai kelemahan, akan tetapi dapat menghilangkan permusuhan dan konflik sehingga dapat menjadi pemersatu yang luas. Hal tersebut dapat sebagai wadah kehidupan manusia sebagai mahkluk kepentingan. Dengan kebersamaan dalam lingkungan masyarakat, mampu memperkuat jalinan kebersamaan sehingga pendidikan karakter dapat terwujud apabila dilaksanakan dengan bersama-sama dan tanggungjawab bersama.

\section{Pendididikan Karakter dalam Pendidikan Non Akademik Keislaman}

Berdasarkan tujuan pemerintah terhadap anak bangsa, mencerminkan kecerdasan dan berakhlak mulia dalam memajukan bangsa dan negara. Lembaga pendidikan berupaya dan berpedoman pada aturan dan kaidah yang berlaku dalam mencerdaskan anak bangsa. Selain itu lembaga pendidikan, melalui guru sebagai penyampai ilmu pengetahuan berusahan beririentasi pada nilai dalam proses pembelajaran (Fraenkel. 1977:2). Kepala sekolah atau madrasah menerapkan di lingkungan sekolah melalui kurikulum yang dibuat sesuai dengan visi dan misi sekolah atau madrasah tersebut. setiap lembaga pendidikan berupaya mencerdaskan dan menjadikan siswa didik berahklak mulia. Kurikulum sebagai jantung pendidikan, menentukan jenis dan kualitas pendidikan. Selain itu kurikulum 2013 
merupakan penyederhanaan dan tematik-interatif untuk mencetak generasi berikutnya dalam menghadapi masa depan. Kurikulum ini menekankan pada pendekatan fenomena sosial, seni, dan budaya, bertujuan siswa memiliki kompetensi sikap, ketrampilan dan $\mathrm{p}$ engetahuan lebih baik dari sebelumnya. Diharapkan siswa dapat mengikuti perkembangan zaman dengan pemikiran kreatif, inovatif, dan produktif.

Sebagai upaya lembaga pendidikan dalam kegiatan non akademik merupakan salah satu nilai jual dari suatu lembaga pendidikan. Peningkatan prestasi tidak hanya di bidang akademik, tetapi juga bidang non akademik. Ruang lingkup bidang non akademik sebagai kegiatan di luar akademik dalam lembaga pendidikan seperti sekolah dan madrasah, yaitu kegiatan ekstrakkurikuler. Setiap sekolah memiliki pilihan ekstrakurikuler sebagai unggulan di sekolah atau madrasah masing-masing sekolah. Kegiatan ekstrakurikuler merupakan kegiatan pilihan siswa dalam bidang non akademik. Program ini merupakan program unggulan dari masing-masing lembaga pendidikan. Sebagai upaya meningkatkan nilai moral dan ahklak generasi saat ini, program kegiatan eksrakurikuler dipilih dalam penyempurnaan ahlak yaitu kegiataan keagamaan.

Madrasasah berbasis agama Islam biasanya menampilkan program-program ekstrakurikuler keislaman, dengan tujuan membina dan meningkatkan kualitas keimanan dalam nilai-nilai moral. Melalui kegiatan ini, selain mengurangi sikap dan perbuatan negatif atau tidak sesuai dengan etika dan moral, siswa dapat menunjukkan prestasi di bidang keislaman dan sebagai penerus bagi adik-adik kelas atau di kegiatan masyarakat luas. Menyebarkan dan mensosialisasikan keislaman pada kalangan luas, sehingga tetap membudaya dan mengakar dari generasi ke generasi.

Program ekstrakurikuler di sekolah dilaksanakan di luar jam kegiatan pembelajaran informal. Program ini dapat memperkaya dan memperluas wawasan pengetahuan dan pengalaman sehingga ma mpu membina dan mendorong penyaluran hobi, minat, bakat dan mengandung nilai sikap dan moral (Sulistyorini. 2007). Program ini dapat memunculkan daya kreatifitas, kemampuan, dan jiwa spotifitas serta percaya diri. Kegiatan ekstrakurikuler di sekolah atau madrasah berbasis keislaman yang dapat diterapkan adalah tartil Quran, hadrah, hafiz Quran, marawis, band Islami, tahsin, qosidah, kaligrafi, muhadarah, rohis (rohani Islam), dan bulletin keagamaan. Kegiatan tersebut merupakan kegiatan keislaman yang dikemas dengan kesenian, budaya, dan teknologi. Sehingga mampu meningkatkan dan mengasah siswa dalam pengembangan keilmuan dan pengalaman. 
Kemampuan tersebut memiliki nilai tambah, karena siswa dapat menerapkan hasil pembelajaran ekstakurikuler dalam kehidupan sehari-hari. Sebagai contoh, siswa dapat berinteraksi sosial dengan sekitarnya, di lingkungan keluarga, sekolah, dan masyarakat. Dalam kegiatan ekstrakurikuler tersebut, siswa didorong untuk mampu melakukan dengan berkelompok dan individu. Dalam prosesnya siswa mempelajari teori dari ekstrakurikuler tersebut, kemudian menerapkan dalam praktek. Praktek dilakukan secara kelompok dan individu. Pada saat praktek siswa harus konsentrasi dan memahami materi dari keilmuan yang telah dipelajari sebelumnya. Pada saat mempraktekkan atau mempresentasikan siswa dituntut untuk terbiasa dan dapat mengaplikasikannya. Pentingnya siswa mengevaluasi diri secara obyektif sehingga memerlukan kecerdasan dalam berpikir dan bertindak, sepertti pernyataan Edward (1949) bahwa, kecerdasan memiliki tiga tipe yaitu riil, kecerdasan abstrak, dan kecerdasan sosial.

Kecerdasaan riil, kemampuan individu untuk menghadapi situasi dan benda-benda nyata. Kecerdasan abstrak, kemampuan individu untuk memahami kata-kata, bilangan, huruf, simbol, dan rumus-rumus. Kecerdasan sosial, kemampuan individu untuk mengadapi dan merespon situasi sosial atau kehidupan masyarakat. Siswa mampu berinteraksi sosial di lingkungan masyarakat dengan mengerti dan mengikuti aturan dan kaidah sosial sehingga dapat diterima masyarakat. Selain kecerdasan juga harus memiliki mental yang mampu bertahan dan bereaksi terhadap sekitar. Berdasarkan pendapat Notosoedirjo dan Latipun (2005), bahwa mental sehat: (a) Seseorang melakukan penyesuaian diri dalam merespon situasi sosial sehingga tidak pasif tetapi menguasai dan mengontrol lingkungannya; (b) kepribadian yang stabil, karena mampu mempertahankan integritas diri; (c) mampu memposisikan diri dengan benar dan percaya diri dalam kebutuhan pribadi.

\section{Penerapan Adab Melalui Pendidikan Non Akademik Keislaman}

Anjuran Allah untuk berperilaku dengan ahlak dan adab yang sopan dan bersifat terpuji (Fattah. 1966: 10). Pentingnya perilaku berdasarkan ajaran Allah, sehingga dapat mewujudkan kehidupan yang sejahtera. Penerapan adab dilakukan dalam kehidupan sehari-hari melalui pengawasan orangtua dan pendidik. Penerapan dalam lingkungan sekolah dilakukan dengan mengikuti peraturan sekolah. Perilaku baik diperlukan melebihi ilmu pengetahuan. Dengan perilaku baik, telah menerapkan keilmuan yang didapat selama pembelajaran baik formal ataupun nonformal. Apabila tidak memiliki adab, yang terjadi 
adalah keburukan dan kebodohan, karena menuruti hawa nafsu tanpa adanya batasan ataupun aturan yang mengikuti.

Berdasarkan pernyataan dari Quraish Shihab (1994: 40), bahwa Alquran memuat akidah dan kepercayaan dalam keimanan dan keesaan Allah, dan pastinya akan dating hari pembalasan bagi orang yang tidak beriman. Al-Quran memuat syariah dan hukum, bahwa norma agama dan asusila harus dijalani dan ditaati oleh manusia dalam kehidupan seharihari. Bahwasanya manusia harus dapat menjalani dan menerapkan dalam kehidupan sehari-hari sesuai dengan pedoman hidup Islam yaitu Alquran.

Penerapan yang dilakukan dalam kehidupan sehari-hari pada lembaga pendidikan, yaitu pembelajaran dan bermain. Melalui pembelajaran secara akademik maupun non akademik. Sehubungan dengan penulisan pada bidang non akademik, yaitu kegiatan ekstrakurikuler. Kegiatan ekstrakurikuler yang merupakan kegiatan non akademik, khususnya kegiatan tersebut dibidang keislaman. Berdasarkan alquran yang merupakan pedoman hidup umat Islam, harus dipenuhi secara kaffah dan terimplementasi dalam kehidupan sehari-hari. Hal ini dapat menghindari calon pemimpin atau generasi penerus dari perbuatan buruk dan tidak terpuji, jauh dari ajaran Allah.

Pendididkan non akdemik yang dipresentasikan dalam penulisan ini adalah kegiatan ekstrakurikuler berbasis keislaman di sekolah Islam. Setiap sekolah ingin mennyajikan dan menyediakan ekstrakurikuler yang berkarakter dan berprestasi sehingga dapat menarik minat orangtua untuk mendaftarkan dan belajar di sekolah tersebut. Setiap sekolah memiliki ekstrakurikuler yang berbeda, berdasarkan kompetensi sumber daya manusia yang memiliki keahlian dan jalur prestasi dalam meningkatkan dan menguji kemampuan selama memeroleh keilmuan dan praktek.

Pada sekolah menengah pertama berbasis keislaman, memiliki ekstrakurikuler muhadharah, latihan berpidato. Kegiatan ini dilakuka secara periodik setiap minggu dengan bimbingan kakak kelas atau OSIS dan pelatih yang berkompetensi dibidangnya. Melalui pembinaan, kegiatan muhadharah melatih membiasakan siswa berpidato di depan umum, agar berani tampil di depan umum, terampil berkomunikasi di depan umum, melatih berdakwah amar ma'ruf nahi munkar, siap menjadi calon dai atau pemimpin di masa mendatang.

Sesuai dengan pendapat Sulhan (2010: 15-16), proses pembentukan karakter pada siswa, dengan memasukan nilai kebaikan. Hal ini telah terdapat dalam berbicara depan umum dengan tema keagamaan disertai dengan ayat Alquran, sehingga telah mengandung nila-nilai kebaikan. Hal ini mendukung siswa untuk berbuat baik, dengan tidak langsung 
telah memperlajari keislaman dengan kafah dan disampaikan melalui kegiatan muhadharah. Siswa telah memiliki pemahaman kebaikan sehingga memunculkan rasa keinginan untuk berbuat baik dan mampu mengembangkan sikap cinta kebiakan. Tanpa sadar memunculkan slogan kebaikan dalam berpidato di depan umum. Kegiatan ini, tentu dipantau secara intensif, agar tidak menyimpang dari kaidah agama, menghindari kesalahan dalam pemahaman dari ayat alquran, kebiasaan berbicara, kebiasaan di masjid dan aplikasi pada kegiatan muhadharah.

Pada siswa yang memiliki pribadi atau sikap pemalu, siswa tersebut akan terdorong secara tidak langsung mempresentasikan keahliannya di depan teman-temannya, inilah pola pembelajaran dalam ekstrakurikuler. Siswa secara perlahan akan mampu menunjukkan hasil pembelajaran dari ekstrakurikuler yang telah dipelajari dan dipraktekkan di depan teman-teman dalam komunitas ekstrakuler tersebut. Siswa tidak menyadari bahwa diri individu secara tidak langsung mengalami perubahan dalam pergaulan dan bersikap di depan orang banyak. Rasa percaya diri mulai muncul dan diterapkan di setiap kegiatan, khususnya di sekolah. Keadaan ini biasa dijumpai pada jenjang pendidikan sekolah menengah pertama dan sekolah menengah atas.

Perubahan perilaku siswa tentunya melalui proses panjang dan bertahap. Tidak semua menunjukkan hasil yang signifikan. Hasil survey pada salah satu sekolah menengah pertama, tampak siswa dapat menunjukkan keberanian, kreatifitas, pemikiran, dan perilaku baik dalam interaksi kegiatan sekolah. Siswa dalam menjalankan kegiatan sekolah seperti kegiatan pesantren kilat dapat menunjukkan dengan melatih dan membina adik kelasnya. Perubahan siswa tersebut merupakan kebanggaan dari pembina yang telah melatih, mengarahkan, dan mengawasi kegiatan mereka pada muhadharah. Sehingga para pendidik di sekolah tersebut secara periodik melaksanakan kegiatan ektrakurikuler wajib untuk muhadarah, disini tampak jelas bermunculan para pemimpin muda dan memudahkan mengatur siswa sesuai dengan tugas yang diberikan pendidik untuk membina dan melatih adik-adik kelas. Kemandirian pada siswa tersebut mulai tampak dan dapat memutuskan dan memberlakukan hal yang seharusnya dilaksanakan dan diterapkan dalam kegiatan sekolah baik formal dan informal.

Tentunya kenakalan siswa masih ada, tetapi dapat diatasi dengan baik dan tidak membuat sesuatu yang memalukan dengan menjelekan nama sekolah. Melihat pada usia anak remaja, sangat rentan perilaku yang mangarah pada emosi tinggi dalam memenuhi keinginan atau kepuasan (Elizabeth. 2003:206). Usia adolescence atau masa puber, memiliki kemantangan mental, sosial, emosional dan perubahan intelektual. Sehingga 
mereka merasa telah dewasa dan memiliki pemikiran remaja adalah suatu masa peralihan dari masa kanak-kanak menuju kemasa dewasa, dengan ditandai individu telah mengalami perkembangan-perkembangan atau pertumbuhan-pertumbuhan yang sangat pesat di segala bidang, yang meliputi dari perubahan fisik yang menunjukkan kematangan organ reproduksi. Pentingnya pengawasan dari orang dewasa, khusunya orang tua di rumah dan pendidik di sekolah.

Demikian pula dengan kegiatan ekstrakulrikuler keislaman lainnya, seperti rebana. Dengan latihan berkala, mereka dapat mempelajari alat musik rebana. Menurut Banoe (2007: 354), rebana merupakan alat musik tradisional berupa kendang pada satu sisi besarnya dan bentuknya bundar sesuai dengan genggaman tangan. Bentuk rebana ada yang menggunakan kericikan ada yang tidak menggunakan kericikan. Alat music ini dapat mengeluarkan bunyi tinggi, sedang, dan rendah dengan bergema dan tidak bergema. Perbedaan bunyi akan terdengan dengan cara memukul rebana.

Seni musik adalah bagian dari budaya dan dalam pendidikan akademik termasuk pelajaran seni budaya. Pendidikan seni musik terdapat dalam Peraturan Pemerintah Nomor 19 Tahun 2005, bahwa tujuan mata pelajaran Seni Budaya untuk sekolah menengah pertama atau madrasah adalah sebagai berikut: (1) Memahami konsep dan pentingnya seni budaya, (2) Menampilkan sikap apresiatif terhadap seni budaya, (3) Menampilkan kreativitas melalui seni budaya, (4) Menampilkan peran serta dalam seni budaya dalam tingkat lokal, regional, maupun global. Pelajaran seni budaya dikenalkan alat musik tradisional. Dan sebagian sekolah memasukan dalam kegiatan ekstakurikuler.

Kegiatan ekstrakurikuler musik rebana dilakukan beberapa siswa dengan binaan dan pengawasan pendidik yang berkompeten dilakukan setiap minggu sekali. Siswa yang mengikuti tidak harus bias dengan musik tersebut. Melalui latihan dan binaan secara periodic dapat dipelajari dan dipraktekan. Kegiatan ekstra ini aadalah untuk mengajak dan mengenalkan siswa dengan alat tradisional. Tidak menutup kemungkinan, apabila ada siswa yang sudah mahir dengan alat musik tersebut. Biasanya siswa yang kemampuannya lebih dari lainnya, akan membantu membimbing siswa lain, sehingga praktek musik rebana dapat benrjalan dengan intens dan efektif. Secara tidak langsung siswa yang sebelumnya tidak bias bermain rebana, dengan terus berlatih, akhirnya mengusai musik tersebut. Pembelajaran musik rebana mengarahkan siswa lebih menguasai musik daerah dan mengasah jiwa kepemimpinan, serta keislaman. Karena lirik dari musik rebana ini menggunakan lirik religi, sholawat. Rebana merupakan salah satu strategi dalm syiar agama Islam. Musik dan lirik yang mengandung keislaman merupakan salah satu media 
dalam mengikis perilaku tidak baik dan perlu dilestarikan pada masa kini yang mulai tergerus budaya modern. Melalui solawat dengan musik rebana, siswa dapat menghafal secara tidak langsung dan dapat menggugah perasaan dan hati nurani serta lebih mawas diri secara individu dalam berinteraksi sosial.

Kegiatan ekstakurikuler keislaman membantu mengurangi dan mengatasi kenakalan remaja. Melalui kegitan tersebut siswa dapat menunjukan nilai-nilai karakkter yang telah ditanamkan melalui kegiatan ekstakurikuler melipti nilai religius, mandiri, tanggunjawab, jiwa kepemimpinan, disiplin, saling menyayangi dan menghargai. Metode yang digunakan melalui pendekatan dan pembiasaan. Penanaman nilai-nilai karakter yang telah diberikan dan tersampaikan memiliki dampak yang berbeda. Pentingnya dukungan orang disekitar dan tempat mereka menimplemenatsikan keilmuan yang telah diperoleh dalam kegiatan apresiasi prestasi. Kebanggan seorang siswa apabila telah menampilkan keahlian yang telah ditempuh dalam jangka periodik dan lama, serta ketekunan. Mereka merasa kecewa apabila ajang tempat mereka mengapresiasikan keahliannya tidak atau belum tersedia. Biasanya setiap sekolah mengadakan pesta seni atau ajang kesenian diakhir semester, sebagai ajang tunjuk prestasi dan keahlian. Dukungan pendidik, komite, dan orangtua siswa sangat dibutuhkan, sehingga tidak mematahkan semnagt siswa dan merasa dihargai atas waktu, segala jerih payah, dan pemikiran. Apresiasi lingkungan dengan mengadakan ajang tersebut dan memotivasi dengan hadiah-hadiah dan menyebutkan tingkatan prestasi mereka.

\section{Kesimpulan}

Setiap lembaga pendidikan memiliki tujuan dan goal atas hasil belajar dan prestasi siswa. Upaya pemasaran atau publikasi setiap lembaga pendidikan memilikij nilai jual keberhasilan siswa baik prestasi dan ahklak siswa, dengan ahklak baik siswa secara tidak langsung telah menunjukkan prestasi. Kebanggan sekolah merupakan kebangaan orangtua siswa itu sendiri. Sehingga sekolah berupaya memiliki sumber daya manusia dan ruang belajar berdasarkan standar pendidikan dan berkompeten.

Selain itu sekolah berusaha dengan meningkatkan ahklak dan adab siswa menjadi lebih baik. Penerapan adab melalui pendidikan non akademik keislaman merupakan salah satu pilihan dalam mengatasi permasalahan perilaku siswa yang mengalami penurunan dalam beretika dan bersikap, serta merosotnya nilai-nilai moral. Melalui pendidikan non akademik dengan ekstrakurikuler berbasis keislaman dapat megatasi dan mengurangi adab siswa dalam berinteraksi sosial di lingkungan keluarga, sekolah, dan masyarakat. 
Pembinaan dan pelayihan yang dlakukan atau dilaksanakan secara periodik mampu menanamkan nilai-nilai agama dan nilai-nilai moral pada ranah sekolah, sehingga dengan berseiringnya waktu siswa dapat menunjukkan prestasinya dihadapan teman-teman, para guru, orang tua, dan lingkungan sekitar. Tentunya prestasi setiap siswa berbeda-beda sesuai dengan respon atau daya serap dalam memahami materi dan pelatihan, serta tidak menutup kemungkinan dukungan orang terdekat dan lingkungan siswa. Dengan rutinitas yang dijalani sudah merupakan tindakan terpuji dan bernilai moral serta religius, karena penanaman agama Islam telah melekat dan terlaksana dikehidupan hari-hari siswa tersebut.

\section{DAFTAR PUSTAKA}

Abdulsyani. 2007. Sosiologi Skematika, Teori dan Terapan. Jakarta: PT Bumi Aksara.

Banoe, Ponio. 2003. Kamus Musik. Yogyakarta: Kanisius.

Edward Lee Thorndike: 1874-1949. The American Journal of Psikology. Google Scolar.

Elizabeth B. Hurlock. 2003. Psikologi Perkembangan. Jakarta: Erlangga.

Fattah, Abdul. 1966. Adab Islam. terj.Moh Suri Sudahri A. Jakarta Timur: Pustaka ALKautsa.

Fraenkel, Jack R. 1977. How to Teach about Values: An Analytical Approach, Englewood, NJ: Prentice Hall

Ihsan, Fuad. 2005. Dasar-Dasar Kependidikan. Jakarta: Rineka Cipta.

Rusn, Abidin Ibnu. 1994. Pemikiran Al-Ghazali Tentang Pendidikan. Yogyakarta: Pustaka Pelajar.

Keosoema, Doni. 2010. Pendidikan Karakter Integral. Kompas, diambil tanggal 11 Februari 2010.

Shihab, M. Quraish. 1994. Membumikan Al-Quran: Fungsi dan Peran Wahyu dalam Kehidupan Masyarakat. Bandung: Mizan.

Sulisyorini. 2007. Model Pembelajaran IPA Sekolah Dasar dan Penerapannya dalam KTSP. Semarang: Tiara Wacana

Sulhan, Najib. 2010. Pendidikan Berbasis Karakter. Surabaya: PT. JP Press Media Utama. 